\title{
УДК:635.262:631.531.1 \\ https://doi.org/10.53040/gppb7.2021.77 \\ ПОСЕВНЫЕ КАЧЕСТВА НЕСТРЕЛКУЮЩЕГОСЯ ЧЕСНОКА В ЗАВИСИМОСТИ ОТ ПОЛОЖЕНИЯ ЗУБКОВ В ЛУКОВИЦАХ
}

\author{
Килинчук А.И., Ботнарь В.Ф. \\ Институт генетики, физиологии и защиты растений, Кишинэу, Республика Молдова \\ e-mail: alexei.chilinciuc@igfpp.md
}

\begin{abstract}
The location of the cloves influences the growth and development of the plants, as well as the formation of the bulb mass. Peripheral garlic cloves are distinguished by higher quality over internal ones (the mass ratio is within $60: 40 \%$ ). Our studies show that in obtaining high yields of non-clotting garlic, the location of the clove in the bulb is of decisive importance. Studies also found that the use of cloves of different locations without mass calibration for planting, leads to different times of ripening of the bulbs, which complicates the process of harvesting and leads to a deterioration in the quality of garlic. Sorting, with the aim of using similarly ground garlic cloves for planting, ensures the uniform development of the plants, simultaneous of ripening of the bulbs and obtaining better quality products.
\end{abstract}

Key words: non-clothing garlic, shoot, leaves, bulb, garlic cloves, leaf area, planting pattern, weight of planting material, location of the garlic clove.

\section{Введение}

В культуре встречается два вида чеснока: стрелкующий и нестрелкующий. Последний, изза сложности выращивания посадочного материала, занимает относительно небольшие площади, хотя имеет существенные преимущества в процессе хранения. Необходимость выращивания нестрелкующегося чеснока обусловлено содержанием в нём полезных компонентов для питания человека. Кроме того, данный вид отличается относительно большей устойчивостью к болезням и вредителям и более длительным периодом хранения по сравнению со стрелкующий.

Площади, занятые нестрелкующим чесноком, очень малы, производственных посадок нет, однако его возделывают в основном на приусадебных участках, при этом, в основном, используется не сортовой посадочный материал а местные формы. Отсутствие специально отведенных участков и рекомендаций по выращиванию посадочного материала, как и самого нестрелкующегося чеснока, является одной из причин низких урожаев и его ограниченного распространения.

Посадочный материал, завезенный из других географических зон, часто не в полной мере соответствует почвенно-климатическим условиям нашей республики, при этом урожайность, значительно ниже действительно возможного уровня. Поэтому изучение технологических особенностей связанных с производством посадочного материала нестрелкующегося чеснока является весьма актуальными.

Нестрелкующийся чеснок характеризуется плотной луковицей со спиралеобразным размещением зубков. Зубки разнообразной формы и величины, неодинаковы по весу, периферийные крупные (3-7 г), внутренние - мелкие (0,5-3 г). При их использовании в качестве посадочного материала между растениями появляются различия в росте, листообразовании, формировании луковиц, количеству зубков, величине урожая. Следовательно, изучение потенциала продуктивности разных по крупности зубков, в зависимости от их расположения в луковице, (периферийные и внутренние), имеет большое практическое значение и будет способствовать большему интересу фермеров и овощеводов любителей к выращиванию нестрелкующего чеснока.

В связи с чем основная цель исследований состояла в том, чтобы выявить влияние местоположения зубков в луковице в качестве материала посадочного (зубки периферийные и внутренние) на процессы листообразования, размер луковиц, количество и качество урожая и выход посадочного материала.

\section{Материалы и методы}

Объектом исследования явились зубки от выведенной нами популяции нестрелкующегося чеснока путем отселектирования его из местных форм. 
Для сравнительного изучения морфологических особенностей посадочный материал был разделен на две фракции: зубки периферийной части луковицы $\left(\mathrm{B}_{3}\right)$, зубки внутренней части луковицы с удалением мелких, $\left(\mathrm{B}_{2}\right)$ и зубки разного местоположения и без калибровки по массе $\left(\mathrm{B}_{1}\right)$ - контроль. Средняя масса зубков для посадки в вариантах $\left(\mathrm{B}_{3}\right)$ и $\left(\mathrm{B}_{2}\right)$ составляла 3,6 г., тогда как в контрольном варианте включая мелких - 3,2 г. Посадку зубков проводили в конце первой - начали второй декады октября на глубину 6-8 см. Схема посадки - широкополосная четырехстрочная лента $(20+20+20+80$ см), с расстоянием растений в рядке $12-13$ см. Площадь учетной делянки - 2,8 м². Опыты проводили на типичном черноземе, отвечающем требованиям выращивания овощных культур с соблюдением общепринятых правил севооборота без применения орошения $(1 ; 2)$. Повторность опыта - четырехкратная.

\section{Результаты и обсуждение}

Наблюдения за ростом и развития растений в течение вегетации показали ряд морфологических различий. При благоприятных климатических условиях в после посадочный период отмечено осеннее листообразование. При посадке чеснока в первой декаде октября выявлено активное корнеобразование в осенне-зимний период (количество корней на растениях составляло 16-32 шт.). Отселектированная нами из местных форм популяция показала высокую устойчивость к низким температурам, жаре и засухе. Массовые всходы растений с учетом срока посадки наблюдали в начале марта. Различий в продолжительности предвсходовых периодов практически не наблюдалось. Не было различий и в полевой всхожести зубков. Окончание формирования луковиц при благоприятных климатических условиях отмечено в конце июня.

В процессе роста между вариантами обнаружились различия по площади листовой поверхности растений. От месторасположения зубков в луковице зависело и показатель их облиственности (табл.1).

Таблица 1. Влияние местоположения зубков в луковице на формирование площади ассимиляционного аппарата

\begin{tabular}{|c|c|c|c|}
\hline Вариант & $\begin{array}{c}\text { Площадь листового аппарата } \\
\text { одного растения }\left(\mathrm{cm}^{2}\right)\end{array}$ & $\begin{array}{c}\text { Индекс листового } \\
\text { покрытия }\end{array}$ & $\begin{array}{c}\text { \% соотношения к } \\
\text { контролю }\end{array}$ \\
\hline $\mathrm{B}_{1}$ & 321,44 & 0,9 & 100 \\
\hline $\mathrm{B}_{2}$ & 361,44 & 1,01 & 112,4 \\
\hline $\mathrm{B}_{3}$ & 364,29 & 1,02 & 113,4 \\
\hline
\end{tabular}

Анализ данных, приведенные в таблице 1, позволяет заключить, что наибольшей площади ассимилирующих листьев отличались растения, выращенные из периферийных и внутренних зубков, и в зависимости от места их расположения в луковице составила $364,29 \mathrm{~cm}^{2}$ - в третьем, $361,44 \mathrm{~cm}^{2}$ - во втором вариантах и $321,44 \mathrm{~cm}^{2}$ - при использовании на посадку всех зубков без калибровки по массе и местоположения в луковице.

Площадь листовой поверхности у растений, выращенных из периферийных и внутренних зубков, в сравнении с посадкой всех зубков луковицы были на 12-13,4\% больше.

На участках, где были использованы для посадки зубки без калибровки, отмечено значительная неоднородность роста и развития растений. Наблюдаемые различия в формировании ассимиляционного аппарата при использовании периферийных и внутренних зубков, как посадочного материала, в сравнении с использованием на посадку неоткалиброванных зубков, сохранялись в течение всего вегетационного периода.

Местоположение зубка в луковице, в качестве посадочного материала, периферийное и внутреннее, имеет существенное влияние на рост, развитие, образование вегетативной массы и крупности луковиц (табл. 2).

Таблица 2. Влияние местоположения зубка в луковице на рост, образования вегетативной массы растения и веса луковиц

\begin{tabular}{|c|c|c|c|c|}
\hline Вариант & $\begin{array}{c}\text { Общая масса одного } \\
\text { растения (г) }\end{array}$ & $\begin{array}{c}\text { Надземная масса } \\
(г)\end{array}$ & $\begin{array}{c}\text { Средняя масса } \\
\text { луковицы (г) }\end{array}$ & $\begin{array}{c}\text { Высота одного } \\
\text { растения (см) }\end{array}$ \\
\hline $\mathrm{B}_{1}$ & 42,8 & 15,50 & 27,3 & 61,5 \\
\hline $\mathrm{B}_{2}$ & 48,6 & 18,30 & 30,3 & 65,4 \\
\hline $\mathrm{B}_{3}$ & 52,9 & 21,60 & 31,3 & 67,5 \\
\hline
\end{tabular}


Использование на посадку периферийных и внутренних зубков обеспечивает формирование более крупных луковиц. Различия между вариантами в опыте в сравнении с контролем соответственно составляет - 4,0 г периферийные, и 3,0 г - внутренние зубки.

В результате исследований также установлено, что при использовании на посадку зубков разного местоположения без калибровки по массе, в сравнении с периферийными и внутренними зубками, существенно снижает рост, общую массу растений и луковицы. О размерах вышеуказанных показателей можно судить по данным, показанным в таблице 2 , из которых видно, что на вариантах с использованием внутренних и периферийных зубков высота растений составляет 65,4 и 67,5 см, общая масса одного растения - 48,6, и 52,9 г, масса луковицы - 30,3 и 31,3 г, в тоже время при использовании зубков без калибровки по массе, высота растений не превышает 61,5 см, общая масса одного растения составляет - 42,8 г, масса луковицы - 27,3 г. В структуре луковицы количества периферийных зубков превалирует над внутренними (соотношение находится в пределах 60 : $40 \%)$.

Таким образом, установлено влияние местоположения зубка (внутреннее и периферийное) на размер луковиц (табл. 2). Также констатируем, что при использовании периферийного зубка увеличивается и размер луковицы. Если в контрольном варианте, где были посажены зубки разного местоположения без их калибровки по массе, формировались луковицы массой 27,3 г, а в случае где были использованы внутренние зубки, масса луковицы составляет 30,3 г; а при использовании на посадку периферийных зубков, масса луковиц составила 31,3 г. На участках где были использованы зубки разного местоположения без калибровки, формировалось много маленьких луковиц и наименьшая урожайность. Для получения большего урожая чеснока и качественного материала лучше использовать для посадки крупные фракции, преимущественно периферийных зубков.

Таблица 3. Влияние местоположения зубка в луковице на урожайность и качество нестрелкующёгося чеснока

\begin{tabular}{|c|c|c|c|c|c|}
\hline \multirow{2}{*}{ Вариант } & Общий & \multicolumn{3}{|c|}{ Структура урожая, кг/га } \\
\cline { 3 - 6 } & урожай кг/га & \multicolumn{2}{|c|}{ товарный } & \multicolumn{2}{c|}{ нетоварный } \\
\cline { 3 - 6 } & & кг/га & $\%$ & кг/га & $\%$ \\
\hline $\mathrm{B}_{1}$ & 6115,2 & 4651,2 & 76,06 & 1464,0 & 23,94 \\
\hline $\mathrm{B}_{2}$ & 6787,2 & 5841,1 & 86,06 & 946,1 & 13,94 \\
\hline $\mathrm{B}_{3}$ & 7011,2 & 6117,9 & 87,26 & 893,3 & 12,74 \\
\hline
\end{tabular}

Анализ полученных данных продуктивности позволяет отметить, что для формирования высоких урожаев нестрелкующегося чеснока, местоположение зубка в луковице оказывает существенное значение (табл. 3).

На участке, где для посадки были применены зубки без калибровки по массе, общий урожай составил 6115,2 кг/га, тогда как на участке где высадили только внутренние зубки, было получено 6787,2 кг/га, что больше на 672,0 кг/га, в сравнение с контролем, а при использовании периферийных зубков - 7011,2 кг/га, что на 224,0 кг/га больше чем на участке где использовали только внутренние зубки.

Результаты исследований позволяет заключить, что наибольшее повышение урожайности отмечено на варианте с использованием для посадки периферийных зубков, где было получено на 996,0 кг/га в сравнении с контролем и на 226,8 кг/га - в сравнение с вариантом где применяли внутренние зубки.

Согласно проведенным в таблице 3 данным внутренние и периферийные зубки влияют не только на увеличение общего урожая, но и на повышение его товарных качеств. На контрольном варианте величина товарного урожая составила 4651,2 кг/га, тогда как на участке, где были использованы внутренние зубки, товарный урожай составил 5841,1 кг/га, что больше на 1189,9 кг/га, а при использовании периферийных зубков - 6117,9 кг/га, что на 276,8 кг/га больше, чем во втором варианте.

Сравнительный анализ полученных экспериментальных данных указывает, что улучшение товарных качеств чеснока значительнее в варианте $\left(\mathrm{B}_{3}\right)$ с использованием на посадку периферий- 
ных зубков, где прибавка товарного урожая составляет 1466,7 кг/га - в сравнении с контролем и на 276,8 кг/га - с вариантом где использовали только внутренние зубки. Различия в валовом и товарном урожае между вариантами $\left(\mathrm{B}_{3}\right)$ и $\left(\mathrm{B}_{2}\right)$ не столь велики, однако всюду прослеживается преимущество первого.

Исследованиями также установлено, что использование на посадку зубков разного местоположения в луковице без их калибровки по массе приводит к разновременности созревания луковиц, что затрудняет уборку и приводит к дополнительным затратам труда. При этом $24 \%$ урожая составляет мелкие нетоварные луковицы. Использование на посадку одинаковых по массе зубков обеспечивает дружность созревания, большую долю стандартных луковиц и высокие качества посадочного материала.

\section{Выводы}

1. Использование в качестве посадочного материала крупные фракции преимущественно периферийных зубков обеспечивает формирование более высокого урожая и качество луковиц чеснока.

2. В структуре луковицы периферийные имеют более высокие товарные и посадочные качества чем внутренние, соотношение их массы в луковице находится в пределах 60:40\%.

Исследования проведены в рамках проекта Государственной Программы 20.80009.5107.03 «Эффективное использование генетических ресурсов растений и современных биотехнологических методов для повышения адаптивности сельскохозяйственных культур к климатическим изменениям», финансируемой Национальным Агентством по Исследованиям и Развитию.

\section{Литература}

1. БЕЛИК, В.Ф. Методика опытного дела в овощеводстве и бахчеводстве. Москва, ВО «Агропромиздат», 1992. С.319.

2. ДОСПЕХОВ, Б.А. Методика полевого опыта. Москва, Колос, 1979. С.70.

3. Овощеводство Молдавии. Издательство «Картя Молдовеняскэ», Кишинев, 1972. С.357.

4. КИЛИНЧУК, А.И. Лук и чеснок на приусадебном участке. Кишинев, 1997. С. 59. 